\title{
Gaseous mercury distribution in the upper troposphere and lower stratosphere observed onboard the CARIBIC passenger aircraft
}

\author{
F. Slemr ${ }^{1}$, R. Ebinghaus ${ }^{2}$, C. A. M. Brenninkmeijer ${ }^{1}$, M. Hermann ${ }^{3}$, H. H. Kock ${ }^{2}$, B. G. Martinsson ${ }^{4}$, T. Schuck ${ }^{1}$, \\ D. Sprung ${ }^{5}$, P. van Velthoven ${ }^{6}$, A. Zahn $^{5}$, and H. Ziereis ${ }^{7}$ \\ ${ }^{1}$ Max-Planck-Institut für Chemie (MPI), Air Chemistry Division, Joh.-J.-Becherweg 27, 55128 Mainz, Germany \\ ${ }^{2}$ GKSS-Research Centre, Institute for Coastal Research (GKSS), Max-Planck-Str. 1, 21502 Geesthacht, Germany \\ ${ }^{3}$ Leibniz-Institut für Troposphärenforschung (IFT), Permoserstr. 15, 04318 Leipzig, Germany \\ ${ }^{4}$ University of Lund, Division of Nuclear Physics, P.O. Box 118, 22100 Lund, Sweden \\ ${ }^{5}$ Institute for Meteorology and Climate Research (IMK), Forschungszentrum Karlsruhe, Weberstr. 5, \\ 76133 Karlsruhe, Germany \\ ${ }^{6}$ Royal Netherlands Meteorological Institute (KNMI), P.O. Box 201, 3730 AE, de Bilt, The Netherlands \\ ${ }^{7}$ Deutsches Zentrum für Luft- und Raumfahrt (DLR), Institut für Physik der Atmosphäre, 82230 Wessling, Germany
}

Received: 28 July 2008 - Published in Atmos. Chem. Phys. Discuss.: 29 October 2008

Revised: 24 February 2009 - Accepted: 4 March 2009 - Published: 19 March 2009

\begin{abstract}
Total gaseous mercury (TGM) was measured onboard a passenger aircraft during monthly CARIBIC flights (Civil Aircraft for Regular Investigation of the Atmosphere Based on an Instrumented Container) made between May 2005 and March 2007 on the routes Frankfurt-São PauloSantiago de Chile and back and Frankfurt-GuangzhouManila and back. The data provide for the first time an insight into the seasonal distributions of TGM in the upper troposphere and lower stratosphere (UT/LS) of both hemispheres and demonstrate the importance of mercury emissions from biomass burning in the Southern Hemisphere. Numerous plumes were observed in the upper troposphere, the larger of which could be characterized in terms of $\mathrm{Hg} / \mathrm{CO}$ emission ratios and their probable origins. During the flights to China TGM correlated with $\mathrm{CO}$ in the upper troposphere with a seasonally dependent slope reflecting the longer lifetime of elemental mercury when compared to that of $\mathrm{CO}$. A pronounced depletion of TGM was always observed in the extratropical lowermost stratosphere. TGM concentrations there were found to decrease with the increasing concentrations of particles. Combined with the large concentrations of particle bond mercury in the stratosphere observed by others, this finding suggests either a direct conversion of TGM to particle bound mercury or an indirect conversion via
\end{abstract}

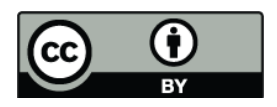

Correspondence to: F. Slemr (slemr@mpch-mainz.mpg.de) a semivolatile bivalent mercury compound. Based on concurrent measurements of $\mathrm{SF}_{6}$ during two flights, the rate of this conversion is estimated to $0.4 \mathrm{ng} \mathrm{m}^{-3} \mathrm{yr}^{-1}$. A zero TGM concentration was not observed during some 200 flight hours in the lowermost stratosphere suggesting an equilibrium between the gaseous and particulate mercury.

\section{Introduction}

The unique physico-chemical properties of mercury render it to be the only heavy metal which is being emitted as elemental vapour into the atmosphere. Once emitted it is transported over long distances because of its slow oxidation rate and low solubility. After oxidation to less volatile and more soluble compounds, mercury can be deposited in remote areas. Its conversion to highly neurotoxic methyl mercury and the bioaccumulation of the latter in the aquatic nutritional chain to concentrations dangerous for humans and animals has motivated intensive research on the biogeochemical cycle of mercury (e.g. Mergler et al., 2007; Scheuhammer et al., 2007; Lindberg et al., 2007, and references therein).

Despite decades of research, the atmospheric mercury cycle is still not well understood (Lin et al., 2006; Lindberg et al., 2007). Several mechanisms of elemental mercury oxidation in the gaseous phase have been proposed (Selin et al., 2007; Holmes et al., 2006) but their relative importance is

Published by Copernicus Publications on behalf of the European Geosciences Union. 
still unknown (Lin et al., 2006). Neither have the oxidation products been unequivocally identified so far because of lack of speciation techniques for individual mercury compounds. In addition, attempts to constrain the atmospheric mercury cycle models relied almost exclusively on ground based measurements in the Northern Hemisphere, which severely compromise their results. Only recently, progress in measurement techniques has enabled extensive but short term aircraft measurements of mercury distribution in the troposphere and lower stratosphere (Ebinghaus and Slemr, 2000; Friedli et al., 2003a, 2004; Banic et al., 2003; Ebinghaus et al., 2007; Radke et al., 2007; Talbot et al., 2007, 2008; Swartzendruber et al., 2008). These measurements have so far provided information about the emissions of mercury from biomass burning (Friedli et al., 2003b; Ebinghaus et al., 2007) and from industrial sources (Friedli et al., 2004; Talbot et al., 2008; Swartzendruber et al., 2008), with sometimes conflicting information about the vertical distribution of mercury (Ebinghaus and Slemr, 2000; Radke et al., 2007; Talbot et al., 2007, 2008). In addition, a pronounced depletion of elemental mercury in stratospheric air masses and air masses influenced by the stratosphere has been observed (Ebinghaus et al., 2007; Radke et al., 2007; Talbot et al., 2007, 2008; Swartzendruber et al., 2008).

In this paper we report the first results of long term mercury measurements in the upper troposphere and lower stratosphere made during monthly CARIBIC (Civil Aircraft for Regular Investigation of the Atmosphere Based on an Instrumented Container) flights (Brenninkmeijer et al., 2007). The observations made over the period from May 2005 to March 2007 will be discussed in terms of mercury emissions, of the mercury distribution in the upper troposphere and of the stratospheric mercury depletion.

\section{Experimental}

The new CARIBIC container (Brenninkmeijer et al., 2007; http://www.caribic-atmospheric.com) onboard an Airbus 340-600 of Lufthansa holds automated analyzers for gaseous mercury, $\mathrm{CO}, \mathrm{O}_{3}, \mathrm{NO}, \mathrm{NO}_{\mathrm{y}}, \mathrm{CO}_{2}$, total and gaseous water vapor, oxygenated organic compounds, and fine particles (three counters for particles with diameters $>4 \mathrm{~nm},>12 \mathrm{~nm}$, and $>18 \mathrm{~nm}$ ), as well as one optical particle counter for particles with diameters $>150 \mathrm{~nm}$. In addition, air and aerosol particle samples are taken in flight and analysed after the flight for greenhouse gases, halocarbons, hydrocarbons, and particle elemental composition and morphology.

The inlet system and instrument tubing are described in detail by Brenninkmeijer et al. (2007). The trace gas probe consists of a $3 \mathrm{~cm}$ inner diameter diffuser tube with a forward facing inlet orifice of $14 \mathrm{~mm}$ diameter and outlet orifice of $12 \mathrm{~mm}$ diameter providing an effective ram pressure of about $90-170 \mathrm{hPa}$ depending on cruising altitude and speed. The inlet cone of the trace gas probe is heated to prevent ic- ing. A small fraction of the air passing through the diffuser is withdrawn from the center flow by a $12 \mathrm{~mm}$ ID PFA lined tube perpendicular to the flow direction. This gas tube, the attached $3 \mathrm{~m}$ long, $16 \mathrm{~mm}$ ID PFA lined transfer tube to the container, and the $1.5 \mathrm{~m}$ long $16 \mathrm{~mm}$ ID PFA tubing within the container to an instrument manifold are heated to $\sim 40^{\circ} \mathrm{C}$. The ram pressure forces about $95 \mathrm{l} / \mathrm{min}$ at $350 \mathrm{hPa}$ of sample air through the main sampling line and the manifold. The air sample for the mercury analyzer is taken at a flow rate of 0.51 (STP)/min from the manifold using the $4 \mathrm{~mm}$ ID PFA tubing heated by the energy dissipated in the container to about $30^{\circ} \mathrm{C}$. The arrangement is similar to that described by Talbot et al. (2008). The large flow through the trace gas diffuser tube of more than $2000 \mathrm{l} / \mathrm{min}$ and perpendicular sampling at much smaller flow rates of about $100 \mathrm{l} / \mathrm{min}$ discriminate against particles larger than about one micrometer diameter (50\% aspiration efficiency, Baron and Willeke, 2001).

The mercury instrument, which is based on an automated dual channel, single amalgamation, cold vapor atomic fluorescence analyzer (Tekran-Analyzer Model 2537 A, Tekran Inc., Toronto, Canada) is described by Brenninkmeijer et al. (2007). The instrument features two gold cartridges. While one is adsorbing mercury during a sampling period, the other is being thermally desorbed using argon as carrier gas. $\mathrm{Hg}$ is detected using cold vapor atomic fluorescence spectroscopy (CVAFS). The functions of the cartridges are then interchanged, allowing continuous sampling of the incoming air stream. A $45 \mathrm{~mm}$ diameter PTFE pre-filter (pore size $0.2 \mu \mathrm{m}$ ) protects the sampling cartridges against contamination by particles which pass through the inlet system. The sample air was compressed from the total pressure at flight altitude (ambient static pressure plus ram pressure) to about $500 \mathrm{hPa}$ needed to operate the instrument with its internal pump. Extensive laboratory tests of this diaphragm pump did show neither any contamination of the system with $\mathrm{Hg}$ nor $\mathrm{Hg}$ losses which would lead to memory effects. To avoid a contamination of the instrument and of the tubing connecting the sampling manifold with the instrument during ascents and descents in heavily polluted areas near most of the larger airports, the sampling pumps are switched only at ambient pressure below $500 \mathrm{hPa}$. Consequently, no measurements below an altitude of about $5 \mathrm{~km}$ are available.

The atomic fluorescence spectroscopy detector (AFS) of the instrument is operated at cabin pressure of $750-1000 \mathrm{hPa}$ (in the analysis mode the detector is decoupled from the inlet pressure). The pressure dependence of the AFS detector sensitivity was extensively investigated in the range of 300 to $1000 \mathrm{hPa}$ and was found to be proportionally dependent on the outlet pressure. The measurements were corrected for this dependence using a pressure transducer in the outlet of AFS detector. This correction is in agreement with earlier findings by Ebinghaus and Slemr (2000) and can be explained in the following way. At low concentrations of elemental mercury and thus small absorption of the excitation radiation from the mercury lamp the fluorimeter signal 
is given by

Signal $=f(\theta) g(\lambda) \phi_{f} P_{o} \sigma L n$

where $f(\theta)$ represents a geometrical factor that is determined by the solid angle of the fluorescing radiation observed by the photodetector, $g(\lambda)$ is a factor defining the wavelength dependent efficiency of the photodetector, $\phi_{f}$ represents the fraction of excited atoms that fluoresce (assuming no quenching), $P_{o}$ is the incident radiation power, $\sigma$ is the absorption cross section of the mercury atoms for the incident ration, $L$ is the path length, and $n$ is the number density of the mercury atoms (Strobel, 1973, modified for this particular case). The pressure dependence of the AFS detector observed by us essentially reflects the pressure dependence of the number density of mercury atoms in the detector and suggests an absence of quenching effects. Swartzendruber et al. (2008) attribute the influence of pressure on the AFS sensitivity to the changing residence time of $\mathrm{Hg}$ atoms in the fluorescence cell. Both explanations lead to the same pressure dependence of the AFS detector sensitivity.

As the number of gas cylinders that supply the instruments in the container is limited, a gas mixture of $0.25 \% \mathrm{CO}_{2}$ in argon is used as operating gas both for the $\mathrm{CO}$ and mercury instruments. The addition of $\mathrm{CO}_{2}$ to argon was found to reduce the sensitivity of the fluorescence detector by $35 \%$. Consequently, the sampling interval had been initially set to $15 \mathrm{~min}$ ( $\sim 225 \mathrm{~km}$ flying distance, flights to March 2006) with an air sample flow rate at STP of $0.51 \mathrm{~min}^{-1}$, and has been reduced to $10 \mathrm{~min}$ since April 2006. The instrument is calibrated after every other flight by repeated injection of known amounts of mercury. A detection limit $\sim 0.1 \mathrm{ng} \mathrm{Hg} \mathrm{m}^{-3}$ and a reproducibility of about $0.05 \mathrm{ng} \mathrm{Hg} \mathrm{m}^{-3}$ is achieved at our operating conditions. All concentrations are reported in $\mathrm{ng} \mathrm{Hg} \mathrm{m}^{-3}$ (STP, i.e. 1013.25 hPA and $273.15 \mathrm{~K}$ ).

Swartzendruber et al. (2006) suggest that reactive gaseous mercury (RGM) concentrations increase with altitude from a few percent of total gaseous mercury (TGM) near the ground and may reach substantial proportion of TGM at flight altitudes of the CARIBIC aircraft of $8-12 \mathrm{~km}$. RGM is thought to include the gaseous bivalent products of GEM oxidation such as $\mathrm{HgO}$ and $\mathrm{HgBr}_{2}$ (Lin et al., 2006) but is, in absence of substance specific analytical techniques, defined operationally as mercury compounds which are adsorbed by $\mathrm{KCl}$ coated denuder (e.g. Munthe et al., 2001; Landis et al., 2002). Opposite to gaseous elemental mercury (GEM) which is not influenced by PFA surfaces, the RGM compounds are known to be sticky and substantial losses of RGM in inlet systems have been reported for ground based measurements (Landis et al., 2002; Swartzendruber et al., 2008). On the other side Temme et al. (2003a) reported no RGM losses in the sampling tubing during TGM measurements in Antarctica at conditions similar to that encountered by us in the upper troposphere and lower stratosphere (UT/LS), i.e. at low humidity and low temperature. To find out whether RGM is being measured by our instrument, a soda lime trap was inserted downstream of the PTFE filter and upstream of one of the two gold traps in the instrument. Soda lime trap is known to trap quantitatively RGM while passing through GEM (Prestbo and Bloom, 1995; Landis et al., 2002). Mercury measured with the soda lime trap was substantially lower than mercury measured without the trap in the upper troposphere during several flights, and reached occasionally zero concentrations in the lower stratosphere. This observation is in agreement with a recent report of zero GEM concentrations in upper troposphere $(8-12 \mathrm{~km}$ ) by Talbot et al. (2007). Mercury observed with the gold collector without the soda lime trap must then have consisted entirely of RGM. These observations demonstrate that a substantial part of RGM is transmitted by our inlet system to the instrument. A quantitative determination of the RGM sampling efficiency would require a standard RGM addition in the inlet during the flight which is currently challenging even onboard a research aircraft. Within the constraints imposed by the container operation onboard a passenger aircraft, it is not feasible. Consequently, for a final judgment on the RGM sampling efficiency we have to wait for fly-by intercomparisons with mercury speciation measurements onboard a research aircraft. Nevertheless, the experiments with the soda lime trap demonstrated that a substantial part of RGM is being measured by our system. Based on measurements made by Temme at al. (2003a) we assume that our measurements represent or are close to total gaseous mercury (TGM) and we refer to them as such.

The data reported here were obtained between May 2005 and March 2007 during CARIBIC flights listed in Table 1. Seven of these flights were conducted on the route Frankfurt-São Paulo-Santiago de Chile and twelve on the route Frankfurt-Guangzhou-Manila and back with flight paths shown in Fig. 1. The altitude of the long range flights varies typically from about $9 \mathrm{~km}$ at the beginning of the flight to about $11-12 \mathrm{~km}$ at the end. All flights consisted of 4 individually numbered legs. In addition to the meteorological data provided by the aircraft, meteorological parameters along the flight track were calculated from the ECMWF (European Centre for Medium Range Weather Forecasts) data (6-hourly, 60 model levels until February 2006 and 90 model levels thererafter, $1^{\circ} \times 1^{\circ}$ horizontal resolution). Eight day backward, 3-D kinematic trajectories were calculated with the KNMI model TRAJKS (Scheele et al., 1996) at one minute intervals along the flight path. Consequently, 15 or 10 trajectories were available for each mercury measurement.

For the data evaluation, the complementary continuous meteorological and chemical data were averaged to the sampling intervals of mercury measurements. Wherever slopes of correlation lines are mentioned, they are calculated using orthogonal (major axis) regressions (York, 1966; Cantrell, 2008) which take into account the measurement uncertainties of both correlated parameters. For $\mathrm{Hg} / \mathrm{CO}$ correlations the measurement uncertainties for TGM and CO were set to $0.05 \mathrm{ng} \mathrm{m}^{-3}$ and $1 \mathrm{ppb}$, respectively. 
Table 1. CARIBIC flights from May 2005 to March 2007.

\begin{tabular}{llll}
\hline Flight No. & Route & Date & $\begin{array}{l}\text { Time } \\
\text { resolution [min] }\end{array}$ \\
\hline $110-113$ & Frankfurt-Guangzhou-Manila & 19-21 May 2005 & 15 \\
$114-117$ & Frankfurt-São Paulo-Santiago de Chile & 20-22 Jun 2005 & 15 \\
$118-121$ & Frankfurt-São Paulo-Santiago de Chile & 17-29 Jul 2005 & 15 \\
$122-125$ & Frankfurt-São Paulo-Santiago de Chile & 30 Aug-1 Sep 2005 & 15 \\
$126-129$ & Frankfurt-São Paulo-Santiago de Chile & 4-6 Oct 2005 & 15 \\
$130-133$ & Frankfurt-Guangzhou-Manila & 14-16 Nov 2005 & 15 \\
$134-137$ & Frankfurt-São Paulo-Santiago de Chile & 14-16 Dec 2005 & 15 \\
$138-141$ & Frankfurt-São Paulo-Santiago de Chile & 20-22 Feb 2006 & 15 \\
$142-145$ & Frankfurt-São Paulo-Santiago de Chile & 20-22 Mar 2006 & 15 \\
$146-149$ & Frankfurt-Guangzhou-Manila & 27-29 Apr 2006 & 10 \\
$150-153$ & Frankfurt-Guangzhou-Manila & 29-31 May 2006 & 10 \\
$154-157$ & Frankfurt-Guangzhou-Manila & 5-7 Jul 2006 & 10 \\
$158-161$ & Frankfurt-Guangzhou-Manila & 31 Jul-2 Aug 2006 & 10 \\
$162-165$ & Frankfurt-Guangzhou-Manila & 7-9 Sep 2006 & 10 \\
$166-169$ & Frankfurt-Guangzhou-Manila & 20-21 Oct 2006 & 10 \\
$170-173$ & Frankfurt-Guangzhou-Manila & 14-16 Nov 2006 & 10 \\
$174-177$ & Frankfurt-Guangzhou-Manila & 13-15 Dec 2006 & 10 \\
$178-181$ & Frankfurt-Guangzhou-Manila & 5-7 Feb 2007 & 10 \\
$182-185$ & Frankfurt-Guangzhou-Manila & 6-8 Mar 2007 & 10 \\
\hline
\end{tabular}

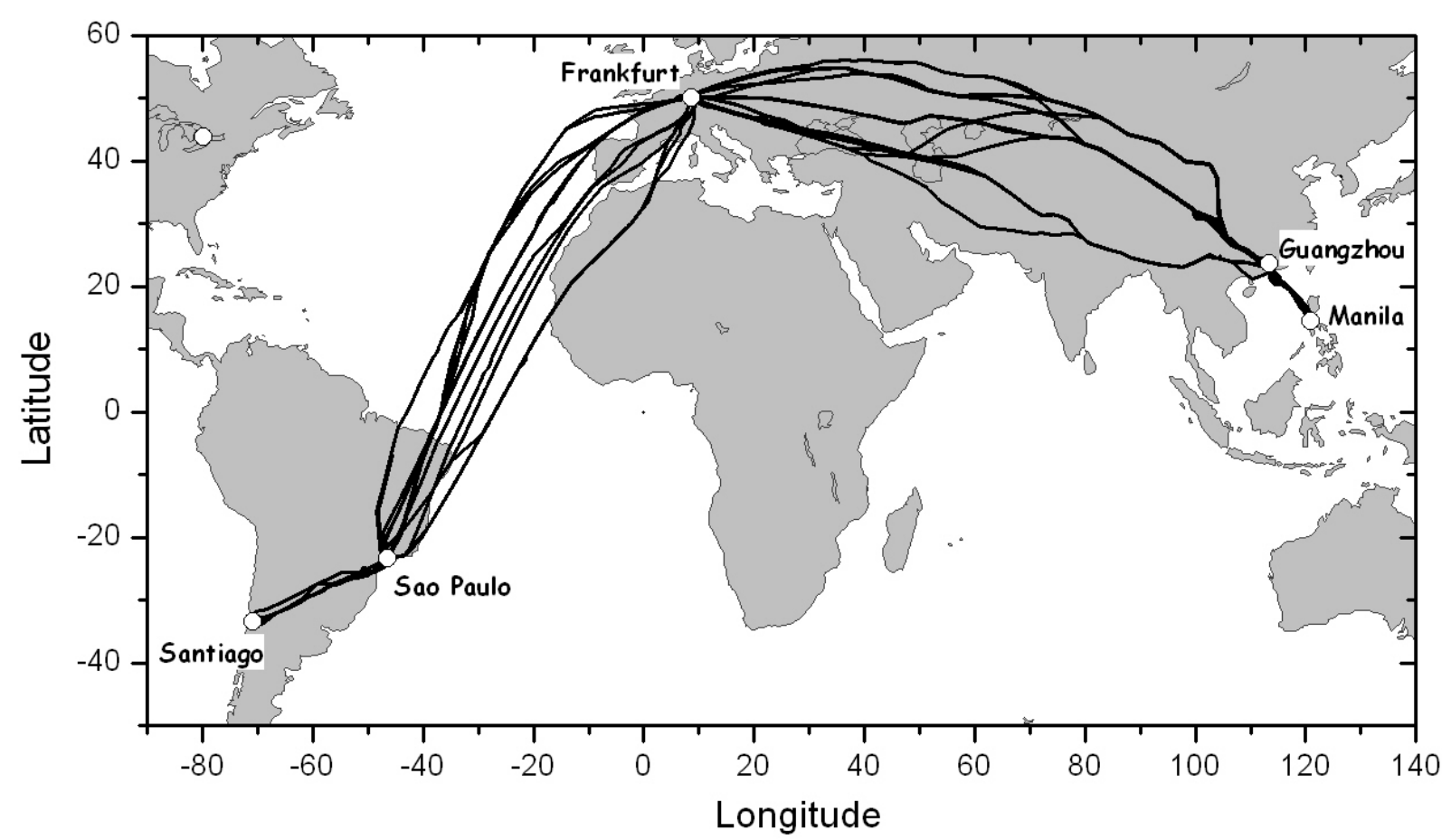

Fig. 1. Tracks of the CARIBIC flights made since December 2004 to March 2007.

\section{Results and discussion}

In this section we will first analyse the distinct mercury plumes observed during the flights to China. The plumes ob- served during the flights to South America originated mostly from biomass burning and their analysis has already been presented by Ebinghaus et al. (2007). In the second part we will discuss a seasonal distribution of TGM in the upper 
troposphere derived for both flight routes. In the last part we will analyse the TGM measurements made above the extratropical tropopause, i.e. within the lowermost stratosphere.

\subsection{Plumes observed during to flights to Guangzhou}

Figure 2 shows an overview of the measurements made during the flight from Frankfurt to Guangzhou on 19-20 October 2006. The potential vorticity (in the uppermost panel below the heading) implies that most of the flight occurred in the upper troposphere $(\mathrm{PV}<2 \mathrm{PVU})$ with two short sections around the tropopause (with $\mathrm{PV}=2.0-3.5 \mathrm{PVU}$ ) before midnight and at about 01:45 UTC on 20 October. This is confirmed by the enhanced ozone of 100-139 ppbv and lower water vapor concentrations of $\sim 30 \mathrm{ppmv}$ shown in the second and third panels. Note that TGM (the lowermost panel) also tends to display lower concentrations during these sections. The $\mathrm{CO}$ concentrations (second panel), $\mathrm{NO}$ and $\mathrm{NO}_{\mathrm{y}}$ concentrations (third) and $\mathrm{CH}_{3} \mathrm{CN}, \mathrm{CH}_{3} \mathrm{COCH}_{3}, \mathrm{CH}_{3} \mathrm{OH}$, and TGM (lowermost) indicate the crossing of four distinct plumes at about 02:00-02:40 (plume A), 03:05-03:45 (plume B), 04:00-04:45 (plume C), and after 05:20 (plume D) at an altitude of $10.2-11.4 \mathrm{~km}$. The plumes each extended over about $600 \mathrm{~km}$ and different ratios of the trace gases in each plume suggest different origins. The last two plumes (C and D) were observed also during the return flight about $14 \mathrm{~h}$ later at pressure altitudes of $8.4-9.6 \mathrm{~km}$ indicating their substantial vertical extent. Enhanced $\mathrm{CH}_{3} \mathrm{CN}$ concentrations in the plume $\mathrm{C}$ indicate a strong contribution from biomass burning.

The 8-day backward trajectories for plumes A and B are similar, starting over the Mediterranean, traversing the Southern Mediterranean coast, then crossing the Mediterranean to the North at about $30^{\circ} \mathrm{E}$ up to Black Sea and heading then east at around $45^{\circ} \mathrm{N}$ (not shown). The trajectories run most of the time at $300 \mathrm{hPa}$. The sections lowest in the troposphere and with a pressure as high as $500 \mathrm{hPa}$ occurred over Southern Spain and Libya from where the observed plumes might originate. In fact, the plumes A and B might be two parts of the same plume separated by a flight section at a lower altitude (see Fig. 2). Backward trajectories for plume $\mathrm{C}$ start above the Eastern Atlantic Ocean above $200 \mathrm{hPa}$, cross the Sahara, Northern Arabic Peninsula, Iran and Pakistan before arriving at about $34^{\circ} \mathrm{N}$ and $95^{\circ} \mathrm{E}$. The lowest point of about $400 \mathrm{hPa}$ was reached above Northern India. Numerous fire counts were detected by satellite in this area which is in agreement with the high $\mathrm{CH}_{3} \mathrm{CN}$ concentrations observed in this plume. The plume $\mathrm{D}$ which is more pronounced during the return flight on 20 October seems to originate mostly from Southern China where the backward trajectories reach $850 \mathrm{hPa}$ or even strike the surface.

$\mathrm{The} \mathrm{Hg} / \mathrm{CO}$ ratios calculated from orthogonal regressions are summarised in Table 2. Regressions were made only for plumes $\mathrm{C}$ and $\mathrm{D}$ of the flight on 20 October since the plumes $\mathrm{A}$ and $\mathrm{B}$ were not observed during the return flights and

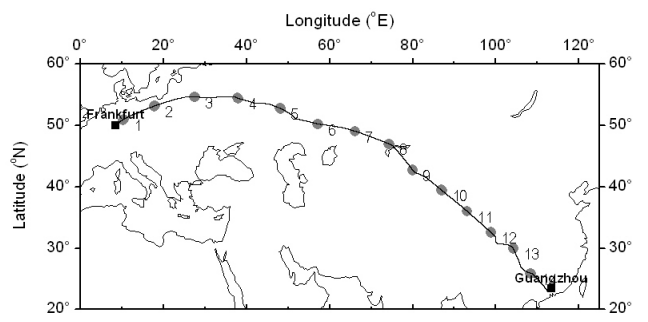

Flight \#166 Frankfurt to Guangzhou, October 19, 2006

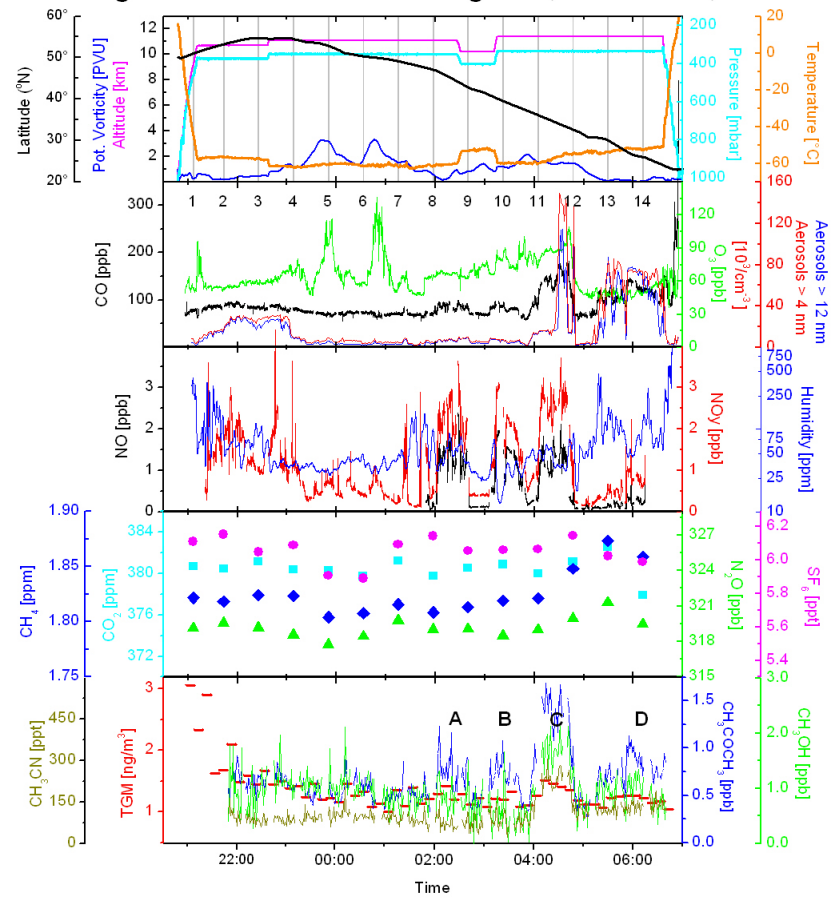

Fig. 2. Overview of the measurements made during the flight \#166 on 19 October 2006, from Frankfurt to Guangzhou.

thus there were not enough points for correlations. Further plumes were observed on 6 July, and 1 August 2006, over the Chinese province of Szechwan and the backward trajectories suggest that Southern China is the probable source area. The correlation on 8 September 2006, essentially reflects the TGM and CO gradients between elevated concentrations over the continental shelf area of South China Sea and low concentrations over Philippines. This and the changing air flow patterns during the flight make it impossible to ascribe the gradient to a specific plume and may be responsible for an unusually high $\mathrm{Hg} / \mathrm{CO}$ ratio. Other $\mathrm{Hg} / \mathrm{CO}$ ratios in Table 2 compare well with about $5 \mathrm{pg} \mathrm{m}^{-3} \mathrm{ppb}^{-1}$ reported recently for Asian outflow in Table 3, except the plume C on 20 October 2006, with a substantially lower ratio. The low $\mathrm{Hg} / \mathrm{CO}$ ratio of the plume $\mathrm{C}$ of $3.9 \mathrm{pg} \mathrm{m}^{-3} \mathrm{ppb}^{-1}$ and the elevated $\mathrm{CH}_{3} \mathrm{CN}$ concentrations indicate a mixture of the emissions typical for Asian outflow with those of biomass burning. 
Table 2. $\mathrm{Hg} / \mathrm{CO}$ ratios in plumes observed during the flights Frankfurt-Guangzhou-Manila and back.

\begin{tabular}{lcccc}
\hline Date & Latitude $\left.{ }^{\circ} \mathrm{N}\right]$ & Longitude [ $\left.{ }^{\circ} \mathrm{E}\right]$ & $\begin{array}{c}\mathrm{Hg} / \mathrm{CO} \text { emission } \\
\text { ratio }\left[\mathrm{ng} \mathrm{m}^{-3} \mathrm{ppb}^{-1}\right]\end{array}$ & $R^{2}, n$, confidence level \\
\hline 6 Jul 2006 & $25.1-31.1$ & $100.3-108.2$ & $6.52 \pm 0.62$ & $0.901,14,>99.9 \%$ \\
1 Aug 2006 & $23.9-30.6$ & $102.4-112.8$ & $7.31 \pm 1.13$ & $0.722,18,>99.9 \%$ \\
8 Sep 2006 & $15.3-22.7$ & $113.6-120.5$ & $9.40 \pm 1.92$ & $0.639,15,>99.9 \%$ \\
20 Oct 2006, plume C & $30.4-38.1$ & $89.5-103.3$ & $3.90 \pm 0.86$ & $0.515,21,>99.9 \%$ \\
20 Oct 2006, plume D & $23.4-31.0$ & $100.2-112.0$ & $6.93 \pm 1.74$ & $0.457,20,>99 \%$ \\
\hline
\end{tabular}

Flights Frankfurt - Sao Paulo - Santiago TGM $\left[\mathrm{ng} \mathrm{m}^{-3}\right.$ ]

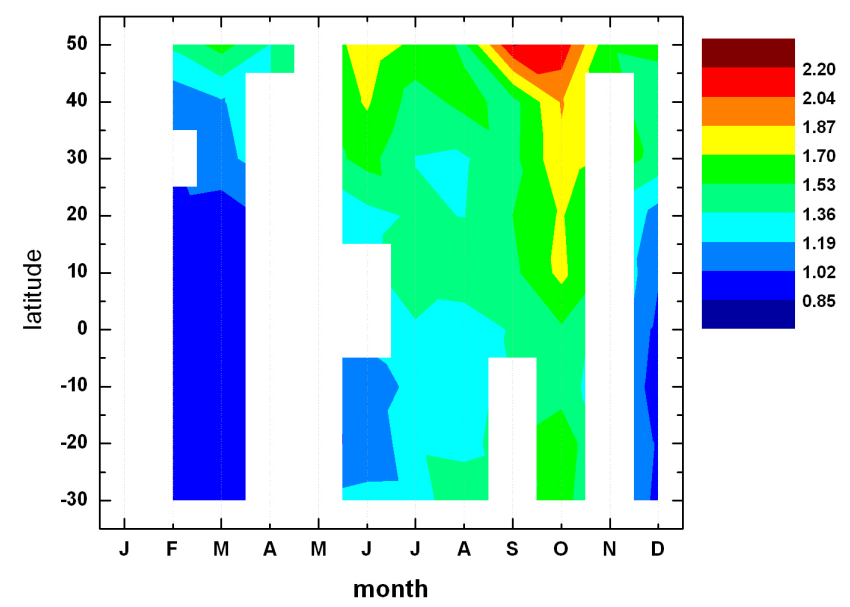

Fig. 3. Time-latitude distribution of tropospheric TGM concentrations observed during the CARIBIC flights from Frankfurt to South America. The data were binned by the month of the year and by $10^{\circ}$ latitude.

\subsection{Distribution of TGM concentrations in the troposphere}

To distinguish between tropospheric and stratospheric air, Zahn et al. (2002) proposed an empirically derived criterium based on the seasonally varying of $\mathrm{O}_{3}$ concentrations at the tropopause in the Northern Hemisphere. Unfortunately, a similar criterium for the Southern Hemisphere is not available. Consequently, for Southern Hemisphere we apply the potential vorticity $(\mathrm{PV})$ criterium of $\mathrm{PV}<-1.5 \mathrm{PVU}$ (1 PVU $=10^{-6} \mathrm{~K} \mathrm{~m}^{2} \mathrm{Kg}^{-1} \mathrm{~s}^{-1}$ ) to distinguish between tropospheric and stratospheric samples. In view of the long sampling times corresponding to a spatial resolution of $150-200 \mathrm{~km}$, a spatially highly resolved description of the tropopause is not required and the use of PV is justified.

\subsubsection{North-South distribution}

The North-South distribution of TGM concentrations was observed during seven flights to South America made be- tween May 2005 and March 2006. Despite several missing monthly measurements (January, April, May, November) we summarized these measurements in Fig. 3 as an annual timelatitude diagram. For this the data were binned by the month of the year and by $10^{\circ}$ latitude. Measurements made over Europe within $45-55^{\circ} \mathrm{N}$ and $3-14^{\circ} \mathrm{E}$ during the flights to China were added to increase the number of data points at northernmost latitudes.

The TGM concentrations peaked around $50^{\circ} \mathrm{N}$ and exhibited a pronounced seasonal variation with a maximum of $\sim 2.2 \mathrm{ng} \mathrm{m}^{-3}$ in September-October and a minimum of $\sim 1.4 \mathrm{ng} \mathrm{m}^{-3}$ in December-April. A secondary maximum of $\sim 1.8 \mathrm{ng} \mathrm{m}^{-3}$ in June can probably be ascribed to enhanced convective activity in the warm season. TGM concentrations show a general latitudinal gradient from higher concentrations in the Northern Hemisphere, where most of the anthropogenic sources are located, to lower values in the Southern Hemisphere $(\mathrm{SH})$. A pronounced seasonal variation is observed at the southernmost latitude of $20-35^{\circ} \mathrm{S}$ with a maximum of $\sim 1.5 \mathrm{ng} \mathrm{m}^{-3}$ in August-October and a minimum of $\sim 0.9 \mathrm{ng} \mathrm{m}^{-3}$ in the austral summer. As described by Ebinghaus et al. (2007) the high SH TGM values observed in August-October were almost always connected with plumes of biomass burning.

The time-latitude distribution can be compared with surface observations and with the distribution of other trace gases. Opposite to a fairly weak and uniform N-S gradient in the upper troposphere, a steep north-south TGM gradient across the ITCZ was observed from ships over the Atlantic Ocean (Slemr et al., 1985; Temme et al., 2003b). This and the increasing amplitude of the seasonal variability above the more northern latitudes of the Northern Hemisphere (NH) are similar to the observed and modeled global $\mathrm{SF}_{6}$ distribution (Gloor et al., 2007) and point to northern midlatitudes as a major mercury source region.

The seasonal variation of mercury concentrations in the $\mathrm{NH}$ at most of the remote surface sites at middle latitudes is characterized by a maximum around March and a minimum around September (e.g. Slemr and Scheel, 1998; Ebinghaus et al., 2002; Kellerhals et al., 2003), although maxima in summer and minima in winter have also been observed at a few sites (e.g. Lindberg et al., 1991). The seasonal variation 
Table 3. An overview of recently reported $\mathrm{Hg} / \mathrm{CO}$ ratios.

\begin{tabular}{|c|c|c|c|}
\hline Source & $\begin{array}{l}\text { Average } \\
{\left[\mathrm{pg} \mathrm{m}^{-3} \mathrm{ppb}^{-1}\right]}\end{array}$ & $\begin{array}{l}\text { Range } \\
{\left[\mathrm{pg} \mathrm{m}^{-3} \mathrm{ppb}^{-1}\right]}\end{array}$ & Reference \\
\hline Shanghai & 6.4 & & Friedli et al. (2004) \\
\hline Asian outflow & $5.6 \pm 1.6(n=6)$ & $3.6-7.4$ & Jaffe et al. (2005) \\
\hline European outflow & $5.0 \pm 2.1(n=15)$ & $1.7-8.4$ & Slemr et al. (2006) \\
\hline Asian outflow & $4.6 \pm 1.3(n=10)$ & $3.2-6.8$ & Weiss-Penzias et al. (2007) \\
\hline US industrial & $1.1 \pm 1.4(n=2)$ & $0.09-2.1$ & Weiss-Penzias et al. (2007) \\
\hline Anchorage & 5.9 & & Talbot et al. (2008) \\
\hline Honolulu & 3.3 & & Talbot et al. (2008) \\
\hline Asian outflow & $6.6 \pm 0.3$ & $6.2-6.8$ & Swartzendruber et al. (2008) \\
\hline Biomass burning & 0.5 & & Friedli et al. $(2003 a, b)$ \\
\hline $\begin{array}{l}\text { Biomass burning, } \\
\text { Pacific Northwest }\end{array}$ & $1.3 \pm 0.8(n=7)$ & $0.4-2.4$ & Weiss-Penzias et al. (2007) \\
\hline $\begin{array}{l}\text { Biomass burning, } \\
\text { Alaska }\end{array}$ & $1.4 \pm 0.6(n=3)$ & $0.8-2.0$ & Weiss-Penzias et al. (2007) \\
\hline $\begin{array}{l}\text { Biomass burning, } \\
\text { South America }\end{array}$ & $1.6 \pm 0.7(n=2)$ & $1.1-2.1$ & Ebinghaus et al. (2007) \\
\hline
\end{tabular}

observed in the upper troposphere of the NH in Fig. 3 with a maximum in September-October thus provides no clear insight into the predominant pattern.

The only available information about seasonal variation in the $\mathrm{SH}$, to our knowledge, is provided by measurements at Cape Point (Slemr et al., 2008). The maximum mercury concentrations at Cape Point over the period 1999-2004 were observed in February and the minimum in August and September. The maximum at the ground is delayed against the maximum in the upper troposphere towards the end of the burning season. N-S transport by the large scale seasonal ITCZ movement with a maximum in December may also contribute to the observed delay (Slemr et al., 2008).

The lack of data in the time-latitude distribution of TGM concentrations in Fig. 3, a substantial interannual variability of the atmospheric mercury concentrations observed at the ground sites (e.g. Ebinghaus et al., 2002), and the lack of mercury monitoring sites in the $\mathrm{SH}$ do not allow to retrieve representative vertical gradients yet. For comparison, only maximum and minimum mercury concentrations at one surface site in each hemisphere are given. At Mace Head $\left(53^{\circ} \mathrm{N}\right)$ with the more typical $\mathrm{NH}$ seasonal variation, the maximum and minimum background mercury concentrations were on average $1.83 \pm 0.07$ and $1.58 \pm 0.07 \mathrm{ng} \mathrm{m}^{-3}$ in March and September, respectively, over the period 19982004. At Cape Point $\left(34^{\circ} \mathrm{S}\right)$ the maximum background mercury concentrations of $\sim 1.34 \mathrm{ng} \mathrm{m}^{-3}$ were observed in February and the minimum of $\sim 1.15 \mathrm{ng} \mathrm{m}^{-3}$ in August and September, averaged over a period 1999-2004 (Slemr et al., 2008).
Flights Frankfurt - Guangzhou - Manila TGM [ng m ${ }^{-3}$ ]

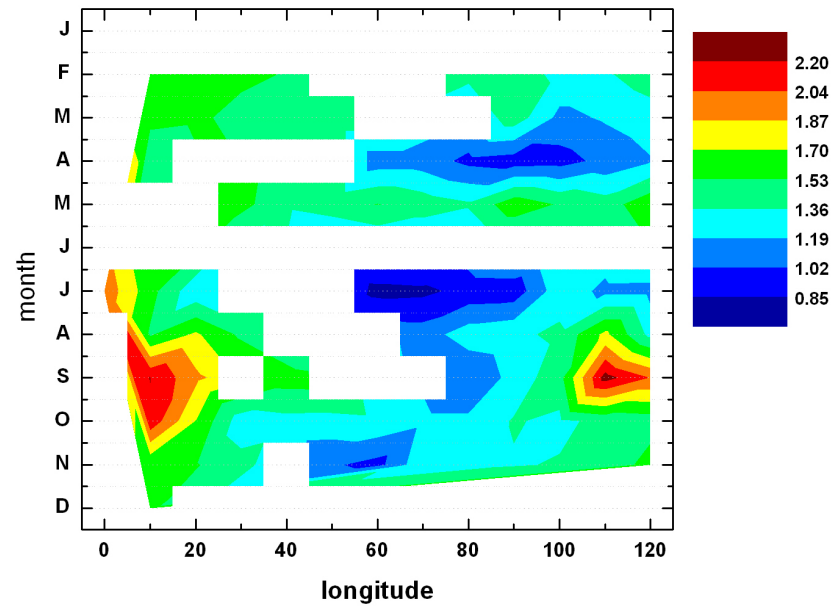

Fig. 4. Time-longitude distribution of tropospheric TGM concentrations observed during the CARIBIC flights from Frankfurt to China. The data were binned by the month of the year and by $10^{\circ}$ longitude.

\subsubsection{Longitudinal distribution in the Northern Hemisphere over Europe and Asia}

The TGM measurements made during the flights on the route Frankfurt-Guangzhou-Manila are summarized in Fig. 4 as a time-longitude concentration map. For this the data were binned by the month of the year and by $10^{\circ}$ longitude. Measurements over Europe within $45-55^{\circ} \mathrm{N}$ and $3-14^{\circ} \mathrm{E}$ made during the flights to South America were added to increase the number of data points in this area. As in Fig. 3, 


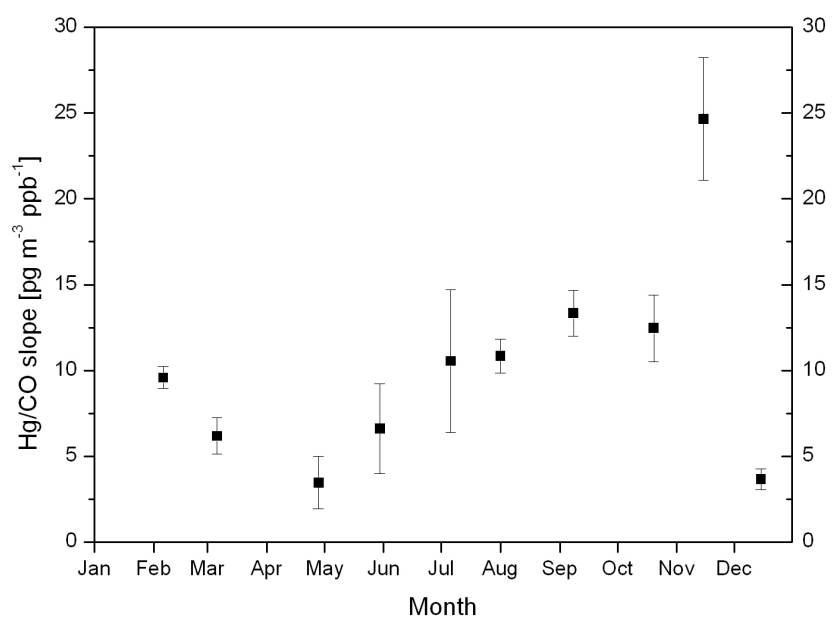

Fig. 5. Seasonal variation of the slopes of TGM-CO correlations observed during the tropospheric sections of the China flights. Only measurements outside of the pollution plumes were considered in these correlations.

the highest TGM concentration were found over Europe with a maximum of $\sim 2.1 \mathrm{ng} \mathrm{m}^{-3}$ in September-October and a broad minimum of about $1.6 \mathrm{ng} \mathrm{m}^{-3}$ from December to April. Low concentrations of $1.1-1.5 \mathrm{ng} \mathrm{m}^{-3}$ without clear seasonal variation were observed between at $50-90^{\circ} \mathrm{E}$. At this longitude flights frequently intersected stratospheric air sections and the low tropospheric TGM concentrations may reflect, despite the PV filter, an influence of the low TGM concentrations in the stratosphere. An alternative explanation, i.e. the low population density within these regions and the correspondingly low mercury emissions, in not likely because of the fast meridional transport in the upper tropospheric midlatitudes.

Further east the TGM concentrations increase and a slight seasonal variation becomes apparent with a maximum of more than $2.0 \mathrm{ng} \mathrm{m}^{-3}$ in September and a minimum of $\sim 1.2 \mathrm{ng} \mathrm{m}^{-3}$ in February-April and June. Taking into account that the measurements at $100-120^{\circ} \mathrm{E}$ span the latitudes of about $30-15^{\circ} \mathrm{N}$, against $45-55^{\circ} \mathrm{N}$ over Europe, the westeast gradient over the whole longitude span of $0-120^{\circ} \mathrm{E}$ is generally in good agreement with the latitudinal gradient between 15 and $55^{\circ} \mathrm{N}$ shown in Fig. 3. The elevated TGM concentrations between 110 and $120^{\circ} \mathrm{E}$ then suggest the influence of the mercury emissions in Southeast Asia which were already discussed in the Sect. 3.1.

The relations of TGM concentrations with other parameters $\left(\mathrm{CO}, \mathrm{H}_{2} \mathrm{O}, \mathrm{O}_{3}, \mathrm{NO}_{\mathrm{y}}\right)$ measured during the flights to Guangzhou and Manila were investigated for the flight sections outside the plumes. The correlations with $\mathrm{CO}$ were the most significant, with the flights on 28 April, 30 May and 6 July 2006 significant at $>95 \%$ level and all other flights significant at $>99.9 \%$ level. The regression slopes of these correlations show a pronounced seasonal pattern displayed in Fig. 5. The smallest $\mathrm{Hg} / \mathrm{CO}$ slopes of $3.46 \pm 1.53$ and $3.67 \pm 0.61 \mathrm{pg} \mathrm{m}^{-3} \mathrm{ppb}^{-1}$ were observed in April and December, respectively, i.e. in spring and winter, the maximum $\mathrm{Hg} / \mathrm{CO}$ slopes around $12 \mathrm{pg} \mathrm{m}^{-3} \mathrm{ppb}^{-1}$ were observed during late summer and early fall. The extreme value observed in November is accompanied by a rather narrow range of low CO concentrations (70-100 ppb) which suggest a possibility of stratospheric influence and is thus considered to be an outlier. The observed seasonal variation of the $\mathrm{Hg} / \mathrm{CO}$ regression slopes seem to result from the seasonal variations both of mercury and $\mathrm{CO}$ and reflects their different tropospheric lifetimes. In winter with longer lifetimes of both mercury and $\mathrm{CO}$ the $\mathrm{Hg} / \mathrm{CO}$ slope should come close to the emission ratios of both species. The wintertime slope of $\sim 3.5 \mathrm{pg} \mathrm{m}^{-3} \mathrm{ppb}^{-1}$ falls well within the range of the $\mathrm{Hg} / \mathrm{CO}$ emission ratios in Table 3 bracketed by high values for industrial emissions and low values from biomass burning. As most of the natural mercury emissions are not accompanied by $\mathrm{CO}$ emissions, the respective $\mathrm{Hg} / \mathrm{CO}$ slope is expected to be smaller than the industrial $\mathrm{Hg} / \mathrm{CO}$ emission ratio.

\subsection{Distribution in the stratosphere}

The most prominent feature of all CARIBIC mercury measurements made so far is the depletion of TGM concentrations in all stratospheric sections of the flights. This feature is well illustrated by the overview of data from flight from Frankfurt to Guangzhou on 6 March 2007, shown in Fig. 6. Apart from the last short flight section, most of the measurements were made in the stratosphere as indicated by the elevated PV (the uppermost panel, blue line), $\mathrm{O}_{3}$ and $\mathrm{NO}_{\mathrm{y}}$ values (the second and third panel from above). TGM concentrations (the lowermost panel) are positively correlated with tracers of tropospheric air such as acetone, $\mathrm{CO}, \mathrm{H}_{2} \mathrm{O}$, $\mathrm{CH}_{4}, \mathrm{CO}_{2}, \mathrm{~N}_{2} \mathrm{O}$, and $\mathrm{SF}_{6}$, and anticorrelated with tracers of stratospheric air such as $\mathrm{PV}, \mathrm{O}_{3}$ and $\mathrm{NO}_{\mathrm{y}}$. Concentrations in air samples taken during the flight and shown in the second panel from the bottom also show a generally positive correlation with TGM. In summary, TGM behaves as most of the trace gases of tropospheric origin with a gradient in the tropopause region towards lower concentrations in the lower stratosphere. Not a single exception from this behavior was observed during some 180 flight hours spent in the stratosphere during the Germany-China and the flights to South America (Ebinghaus et al., 2007). As discussed in the experimental section, a transmission efficiency of RGM from the inlet to the gold traps short of $100 \%$ may also contribute to the reduction of TGM concentrations with increasing proportion of RGM. But as the RGM transmission efficiency of the sampling tubing is high, this process can explain, if at all, only a small part of the observed TGM depletion.

For comparison with the tropospheric $\mathrm{Hg} / \mathrm{CO}$ correlations discussed above, the slopes of the $\mathrm{Hg} / \mathrm{CO}$ regression lines in the stratosphere for the China flights are shown in Fig. 7. Except for the high December value, the slopes vary between 


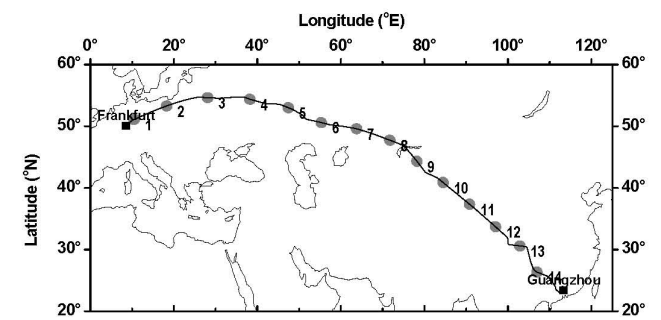

Flight \#182 Frankfurt -> Guangzhou, March 6, 2007

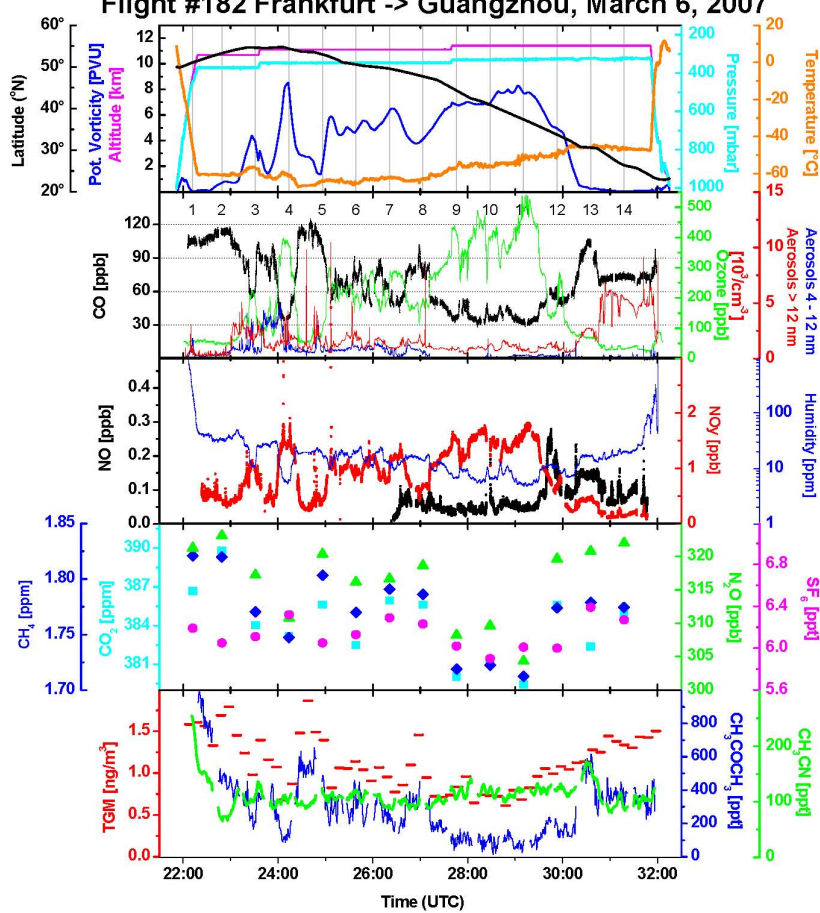

Fig. 6. Overview of the measurements made during the flight \#182 on 6 March 2007, from Frankfurt to Guangzhou.

9.1 to $12.8 \mathrm{pg} \mathrm{m}^{-3} \mathrm{ppb}^{-1}$ without any pronounced seasonal variation. In the SH (South America route) TGM correlated with $\mathrm{CO}$ in five of seven flights. The $\mathrm{Hg} / \mathrm{CO}$ slopes varied from 6.2 to $30.5 \mathrm{pg} \mathrm{m}^{-3} \mathrm{ppb}^{-1}$ with an average of $15.2 \pm 9.5 \mathrm{pg} \mathrm{m}^{-3} \mathrm{ppb}^{-1}(n=5)$. The poorer quality of the $\mathrm{Hg} / \mathrm{CO}$ regressions in the $\mathrm{SH}$ results from the short periods spent in the stratosphere (and thus smaller number of relevant data points), mostly during the flights from São Paulo to Santiago de Chile. As the average $\mathrm{Hg} / \mathrm{CO}$ slope of $10.9 \pm 1.2 \mathrm{pg} \mathrm{m}^{-3} \mathrm{ppb}^{-1}(n=9)$ in the NH cannot be distinguished from that in the $\mathrm{SH}$ we conclude that the $\mathrm{Hg} / \mathrm{CO}$ slopes in the stratosphere are approximately the same in both hemispheres.

The gradients of trace gases with tropospheric origin in the extra-tropical lowermost stratosphere are, depending on the chemical lifetime, partly due to mixing and partly due to the chemical processing. Their proportions can be quantified if the observed air masses can be dated. A substance with a long lifetime and a steadily increasing trend in the

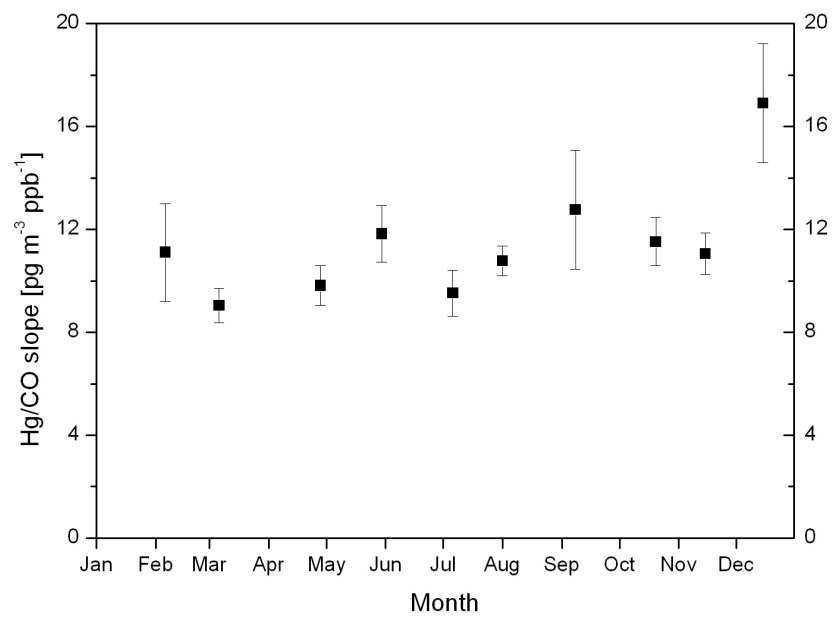

Fig. 7. Seasonal variation of the slopes of TGM-CO correlations observed during the stratospheric sections of the China flights.

troposphere such as $\mathrm{SF}_{6}$ can be used to date the air masses in the lower stratosphere (Stiller et al., 2008). High quality $\mathrm{SF}_{6}$ analyses (Maiss et al., 1996) in whole air samples were available for the China flights 154-157, 158161, and 162-165. TGM correlated with $\mathrm{SF}_{6}$ during the flights 154-157 (5-7 July 2006) and 158-161 (31 July-2 August 2006) with slopes of $1.35 \pm 0.27 \mathrm{ng} \mathrm{m}^{-3} \mathrm{ppt}^{-1}\left(r^{2}=0.78\right.$, $n=9)$ and $2.43 \pm 0.68 \mathrm{ng} \mathrm{m}^{-3} \mathrm{ppt}^{-1}\left(r^{2}=0.59, n=9\right)$, respectively. The correlation during the flights $162-164$ was not significant. The average $\mathrm{Hg} / \mathrm{SF}_{6}$ slope of $1.89 \mathrm{ng} \mathrm{m}^{-3} \mathrm{ppt}^{-1}$ combined with the average annual $\mathrm{SF}_{6}$ concentration increase of $0.230 \mathrm{ppt} \mathrm{yr}^{-1}$ (Stiller et al., 2008) results in a TGM conversion rate of $0.43 \mathrm{ng} \mathrm{m}^{-3} \mathrm{yr}^{-1}$. We caution that this estimate can be considered only as a first approximation because $\mathrm{SF}_{6}$ analyses in whole air samples taken within about $60 \mathrm{~s}$ were combined with TGM measurements with a $10 \mathrm{~min}$ temporal resolution. In addition, the correlations mentioned above cover only three out of 19 flights. Nevertheless, it is the first estimate of the order of TGM depletion rate in the lower stratosphere.

The next question is to which values the TGM depletion in the stratosphere proceeds. The lowest TGM concentration ever measured during some 200 flight hours in the stratosphere of both hemispheres was $0.25 \mathrm{ng} \mathrm{m}^{-3}$ observed during the flight \#146 from Frankfurt to Guangzhou on 26 April 2006. It was accompanied by $\mathrm{O}_{3}$ and $\mathrm{CO}$ concentrations of 634 and $24.4 \mathrm{ppb}$, respectively, and by a calculated PV value of 7.7 PVU. Table 4 summarizes all TGM measurements at $\mathrm{CO}$ concentrations below $30 \mathrm{ppb}$ and $\mathrm{O}_{3}$ concentration above $380 \mathrm{ppb}$ which are considered to be the stratospheric end point of the $\mathrm{CO}-\mathrm{O}_{3}$ mixing lines in the extratropical tropopause region (Pan et al., 2004). We classify them as "deep stratospheric samples". Except of three single measurements, the average deep stratospheric TGM concentrations varied between 0.46 to $0.68 \mathrm{ng} \mathrm{m}^{-3}$ without any apparent seasonal variation. 
Table 4. Average TGM concentrations at $\mathrm{CO}<30 \mathrm{ppb}$ and $\mathrm{O}_{3}>380 \mathrm{ppb}$ which are considered to be the stratospheric end point of the $\mathrm{CO}-\mathrm{O}_{3}$ mixing lines in the extratropical tropopause region (Pan et al., 2004). $n$ is the number of TGM samples. Note that the measurement during the flight \#123 was made in Southern Hemisphere, as indicated also by the negative PV.

\begin{tabular}{lllllrr}
\hline Flight & Route & TGM $\left[\mathrm{ng} \mathrm{m}^{-3}\right]$ & $\mathrm{CO}[\mathrm{ppb}]$ & $\mathrm{O}_{3}[\mathrm{ppb}]$ & $\mathrm{PV}[\mathrm{PVU}]$ & $n$ \\
\hline 123 & São Paulo $\rightarrow$ Santiago & 1.01 & 26.3 & 423 & -7.4 & 1 \\
141 & São Paulo $\rightarrow$ Frankfurt & $0.48 \pm 0.02$ & $25.8 \pm 0.4$ & $554 \pm 33$ & $7.5 \pm 0.1$ & 3 \\
145 & São Paulo $\rightarrow$ Frankfurt & $0.48 \pm 0.03$ & $25.7 \pm 2.4$ & $657 \pm 84$ & $6.7 \pm 0.4$ & 5 \\
149 & Guangzhou $\rightarrow$ Frankfurt & 0.25 & 24.4 & 634 & 7.7 & 1 \\
153 & Guangzhou $\rightarrow$ Frankfurt & $0.47 \pm 0.08$ & $26.4 \pm 2.0$ & $548 \pm 22$ & $7.6 \pm 0.6$ & 6 \\
157 & Guangzhou $\rightarrow$ Frankfurt & $0.46 \pm 0.02$ & $27.6 \pm 0.3$ & $505 \pm 8$ & $7.4 \pm 0.4$ & 2 \\
161 & Guangzhou $\rightarrow$ Frankfurt & $0.66 \pm 0.15$ & $28.9 \pm 0.8$ & $417 \pm 12$ & $10.3 \pm 1.2$ & 3 \\
173 & Guangzhou $\rightarrow$ Frankfurt & 1.05 & 26.9 & 436 & 7.8 & 1 \\
181 & Guangzhou $\rightarrow$ Frankfurt & $0.68 \pm 0.09$ & $27.4 \pm 2.0$ & $593 \pm 56$ & $7.3 \pm 0.2$ & 11 \\
\hline
\end{tabular}

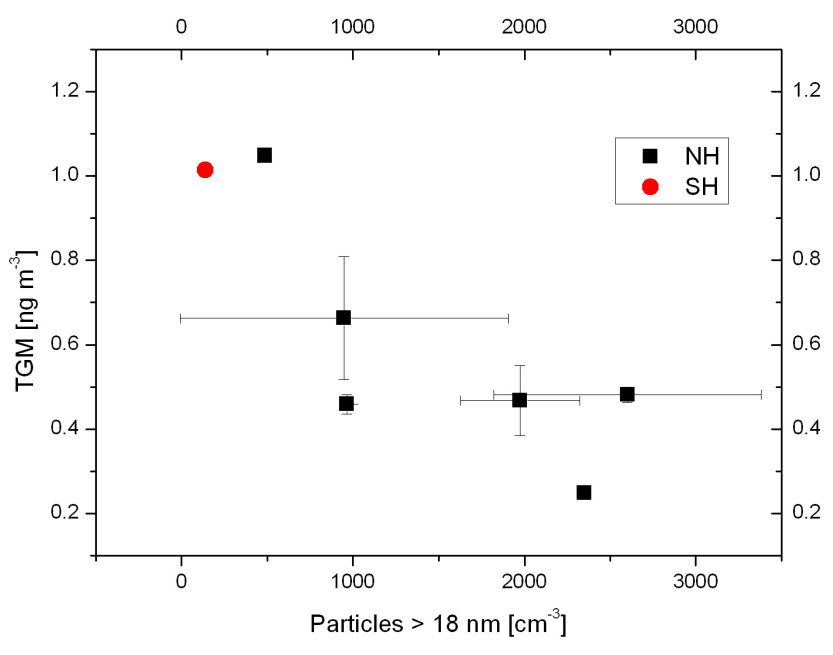

Fig. 8. The relation of stratospheric end point TGM concentrations (i.e. at $\mathrm{CO}<30 \mathrm{ppb}$ and $\mathrm{O}_{3}>380 \mathrm{ppb}$, see Table 4) to particle number concentrations for particles larger than $18 \mathrm{~nm}$. The bars represent the standard deviation of multiple measurements, missing bar mean there is either only one measurement or the bars are smaller than the symbol.

A zero TGM concentration has not been observed so far, not even in the deep stratospheric samples. This might suggest the existence of a dynamic equilibrium between the TGM depletion and a reverse process that recycles TGM. The other possible explanation is a steady state between the TGM import from the troposphere and the TGM depletion in the starosphere.

Deep stratospheric TGM concentrations listed in Table 4 vary between 0.25 and $1.05 \mathrm{ng} \mathrm{m}^{-3}$. Analysis of the data for possible reasons for this variability revealed that they decrease with increasing concentrations of particles larger than 12 and $18 \mathrm{~nm}$, the latter being shown in Fig. 8. Unfortunately, the optical particle counter did not work reliably during these flights and, therefore, no information on the accu- mulation mode particles $(0.1 \mu \mathrm{m}<$ diameter $<1.0 \mu \mathrm{m})$ which are most relevant for the aerosol surface area is available. The observation suggests that elemental mercury or mercury compounds of which RGM consists are attached to particles and the attached amount is dependent on the particle number concentration. The speciation test mentioned in the experimental section and an observation of up to total depletion of gaseous elemental mercury in air masses of partly stratospheric origin reported recently by Talbot et al. $(2007,2008)$ and Swartzendruber et al. (2008) suggest that RGM probably represents a major part of TGM in the stratosphere. In view of the semivolatile characteristics of RGM compounds (possibly $\mathrm{HgO}$ or $\mathrm{HgBr}_{2}$ ) at the temperatures encountered in the UT/LS region it is more likely that it is RGM which is attached to particles.

In summary, Fig. 8 demonstrates convincingly a link between TGM depletion and particle concentrations in the lower stratosphere. This has to be expected because mercury as an element cannot disappear from the air and, thus, the depleted gaseous mercury has to reappear as particulate mercury which is not seen by the CARIBIC instrument. This conclusion is further supported by observations of abundant particulate bound mercury in the lower stratosphere reported by Murphy et al. $(1998,2006)$. Unfortunately, measurements by a particle laser ionization mass spectrometer do not allow a quantitative determination of the particulate bound mercury.

Our attempts to quantify the particulate mercury concentration by PIXE (proton induced x-ray emission) analyses of aerosol particle samples taken during the CARIBIC flights failed so far, despite of the sufficiently low mercury detection limit of the technique. As the aerosol samples are analysed at room temperature and in high vacuum, evaporative losses from the samples of volatile compounds will take place. In a study by Martinsson (1987) aliphatic hydrocarbons were used as model compounds to study losses during analysis. Eicosane with vapor pressure similar to $\mathrm{HgBr}_{2}$ was found 
to be vaporized rapidly in the analytical chamber. Hence $\mathrm{HgBr}_{2}$ with a vapor pressure on the order of $10^{-3} \mathrm{~Pa}$ at $25^{\circ} \mathrm{C}$ most likely escapes the sample in the analytical environment, whereas $\mathrm{HgO}$ with its much lower vapor pressure of $9.2 \times 10^{-12} \mathrm{~Pa}$ at $25^{\circ} \mathrm{C}$ (Schroeder and Munthe, 1998) is expected to remain in the sample during analysis. The failure of mercury quantification on aerosols thus suggest $\mathrm{HgBr}_{2}$ to be a more likely product of the stratospheric TGM depletion than $\mathrm{HgO}$.

Of the three proposed oxidation mechanisms for elemental mercury, the reactions with $\mathrm{OH}$ and $\mathrm{O}_{3}$ (Lin et al., 2006) would lead to $\mathrm{HgO}$ and the reaction with $\mathrm{Br}$ atoms (Holmes et al., 2006) to $\mathrm{HgBr}_{2}$. To the best of our knowledge, no vapor pressure measurements for these compounds are available for temperatures encountered in the lower stratosphere of around $-50^{\circ} \mathrm{C}$ but they can be expected to be about two orders of magnitude lower than those determined at the ambient temperatures. It is thus quite probable that the oxidation products behave as semivolatile substances at the low temperatures in the lower stratosphere with a dynamic equilibrium between particulate and gaseous phase.

\section{Conclusions}

The measurements presented here represent the first systematic observations of TGM in the upper troposphere and lowermost stratosphere over a period of almost two years. The data provide new insights into the seasonal distributions of TGM in the upper troposphere in both hemispheres and demonstrate a substantial influence of biomass burning on the TGM distribution in the Southern Hemisphere.

Numerous individual plumes were observed in the upper troposphere, of which several could be characterized in terms of $\mathrm{Hg} / \mathrm{CO}$ emission ratios. One plume on the route Germany-China with a biomass burning component was attributed to a long range transport from Northern India. All other plumes observed on this route were attributed to sources in China.

During the flights to China TGM correlated with CO in the upper troposphere with a seasonally dependent slope reflecting the different lifetime of $\mathrm{CO}$ and elemental mercury. In winter with long lifetimes of both $\mathrm{CO}$ and TGM the $\mathrm{Hg} / \mathrm{CO}$ slopes fall within the range of the $\mathrm{Hg} / \mathrm{CO}$ emission ratios observed in plumes of industrial areas and of biomass burning. The large scale $\mathrm{Hg} / \mathrm{CO}$ correlations and their seasonal variation may serve as a useful constraint for the global models of tropospheric mercury.

A pronounced depletion of TGM was always observed in the extratropical tropopause layer but the TGM concentrations never reached levels below $0.25 \mathrm{ng} \mathrm{m}^{-3}$. Combined with several observations of a total depletion of elemental mercury reported by Talbot et al. (2007), our TGM observations imply that TGM might be occasionally quantitatively transformed to RGM. Within the extratropical tropopause
TGM correlated positively with $\mathrm{CO}$, acetone and other gases of tropospheric origin, and negatively with $\mathrm{O}_{3}$ and $\mathrm{NO}_{y}$.

The TGM concentrations in deep stratospheric air samples (i.e. stratospheric end of the $\mathrm{CO}-\mathrm{O}_{3}$ mixing lines) were found to decrease with the increasing concentrations of particles larger than 12 and $18 \mathrm{~nm}$. This observation and the large concentrations of particle bond mercury in the stratosphere reported by Murphy et al. $(1998,2006)$ suggests a direct conversion of TGM to particle bound mercury or an indirect conversion via a semivolatile $\mathrm{Hg}^{2+}$ compound. The failure to detect mercury by PIXE on aerosol samples taken during the CARIBIC flights suggests that the more volatile $\mathrm{HgBr}_{2}$ is a more likely product of TGM depletion than the less volatile $\mathrm{HgO}$.

A zero TGM concentration had not been observed during some 200 flight hours in the lower stratosphere. This might either suggest an existence of an equilibrium between the gaseous and particulate mercury or a steady state between the depletion of TGM and its import from the troposphere or both.

Based on concurrent measurements of $\mathrm{SF}_{6}$ the rate of the TGM depletion rate in the lower stratosphere was on the order of $0.4 \mathrm{ng} \mathrm{m}^{-3} \mathrm{yr}^{-1}$ during two flights of three for which precise $\mathrm{SF}_{6}$ measurements were available. Improved precision of $\mathrm{SF}_{6}$ analyses in the future may thus provide more information about the rate of the TGM depletion in the future and the factors influencing it.

The CARIBIC flights have been continued on monthly basis since March 2007 and the measurements are being continually improved. More mercury data on more routes will in the future refine the information about the mercury distribution in the upper troposphere and lower stratosphere and their seasonal variations. Improved precision of the $\mathrm{SF}_{6}$ analyses, measurements of $\mathrm{BrO}$ by differential optical adsorption (DOAS) at the level of the aircraft and measurements of the particle size distribution may provide further information about the rate and mechanism of the depletion of TGM in the lower stratosphere.

Acknowledgements. We thank Lufthansa Airlines and Lufthansa Technik for their commitment and support. High precision $\mathrm{SF}_{6}$ analyses of air samples from flights 154-165 were provided by I. Levin from Institut für Umweltphysik of the University of Heidelberg. We also thank to J. Boedewadt from GKSS for the modifying the Tekran instrument for deployment in the CARIBIC container. The development and operation of the CARIBIC system has been financially supported by the German Ministry of Education and Science (AFO 2000), by the European Commission's DGXII Environment RTD 4th and 5th Framework programs, by grants from the Max Planck Society and from EON-Ruhrgas.

The service charges for this open access publication have been covered by the Max Planck Society.

Edited by: J. W. Bottenheim 


\section{References}

Banic, C. M., Beauchamp, S. T., Tordon, R. J., Schroeder, W. H., Steffen, A., Anlauf, K. A., and Wong, K. H. T.: Vertical distribution of gaseous elemental mercury in Canada, J. Geophys. Res., 108(D9), 4264, doi:10.1029/2002JD002116, 2003.

Baron, P. A. and Willeke, K.: Aerosol Measurements: Principles Techniques and Applications, John Wiley and Sons, New York, 1131 pp., 2001.

Brenninkmeijer, C. A. M., Crutzen, P., Boumard, F., Dauer, T., Dix, B., Ebinghaus, R., Filippi, D., Fischer, H., Franke, H., Frieß, U., Heintzenberg, J., Helleis, F., Hermann, M., Kock, H. H., Koeppel, C., Lelieveld, J., Leuenberger, M., Martinsson, B. G., Miemczyk, S., Moret, H. P., Nguyen, H. N., Nyfeler, P., Oram, D., O’Sullivan, D., Penkett, S., Platt, U., Pupek, M., Ramonet, M., Randa, B., Reichelt, M., Rhee, T. S., Rohwer, J., Rosenfeld, K., Scharffe, D., Schlager, H., Schumann, U., Slemr, F., Sprung, D., Stock, P., Thaler, R., Valentino, F., van Velthoven, P., Waibel, A., Wandel, A., Waschitschek, K., Wiedensohler, A., Xueref-Remy, I., Zahn, A., Zech, U., and Ziereis, H.: Civil Aircraft for the regular investigation of the atmosphere based on an instrumented container: The new CARIBIC system, Atmos. Chem. Phys., 7, 4953-4976, 2007,

http://www.atmos-chem-phys.net/7/4953/2007/.

Cantrell, C. A.: Technical Note: Review of methods for linear leastsquares fitting of data and application to atmospheric chemistry problems, Atmos. Chem. Phys., 8, 5477-5487, 2008,

http://www.atmos-chem-phys.net/8/5477/2008/.

Ebinghaus, R. and Slemr, F.: Aircraft measurements of atmospheric mercury over southern and eastern Germany, Atmos. Environ., 34, 895-903, 2000.

Ebinghaus, R., Kock, H. H., Coggins, A. M., Spain, T. G., Jennings, S. G., and Temme, Ch.: Long-term measurements of atmospheric mercury at Mace Head, Irish west coast, between 1995 and 2001, Atmos. Environ., 36, 5267-5276, 2002.

Ebinghaus, R., Slemr, F., Brenninkmeijer, C. A. M., van Velthoven, P., Zahn, A., Hermann, M., O'Sullivan, D. A., and Oram, D. E.: Emissions of gaseous mercury from biomass burning in South America in 2005 observed during CARIBIC flights, Geophys. Res. Lett., 34, L08813, doi:10.1029/2006GL028866, 2007.

Friedli, H. R., Radke, L. F., Lu, J. Y., Banic, C. M., Leaitch, W. R., and MacPherson, J. I.: Mercury emissions from burning of biomass from temperate North American forests: laboratory and airborne measurements, Atmos. Environ., 37, 253-267, 2003a.

Friedli, H. R., Radke, L. F., Prescott, R., Hobbs, P. V., and Sinha, P.: Mercury emissions from the August 2001 wildfires in Washington State and an agricultural waste fire in Oregon and atmospheric mercury budget estimates, Global Biogeochem. Cy., 17, 1039, doi:10.1029/2002GB001972, 2003b.

Friedli, H. R., Radke, L. F., Prescott, R., Li, P., Wo, J.-H., and Carmichael, G. R.: Mercury in the atmosphere around Japan, Korea, and China as observed during the 2001 ACE-Asia field campaign: Measurements, distributions, sources, and implications, J. Geophys. Res., 109, D19S25, doi:10.1029/2003JD004244, 2004.

Gloor, M., Dlugokencky, E., Brenninkmeijer, C., Horowitz, L., Hurst, D. F., Dutton, G., Crevoisier, C., Machida, T., and Tans, P.: Three-dimensional $\mathrm{SF}_{6}$ data and tropospheric transport simulations: Signals, modeling accuracy, and implications for inverse modeling, J. Geophys. Res., 112, D15112,
doi:10.1029/2006JD007973, 2007.

Holmes, C. D., Jacob, D. J., and Yang, X.: Global lifetime of elemental mercury against oxidation by atomic bromine in the free troposphere, Geophys. Res. Lett., 33, L20808, doi:10.1029/2006GL027176, 2006.

Jaffe, D., Prestbo, E., Swartzendruber, P., Weiss-Penzias, P., Kato, S., Takami, A., Hatakeyama, S., and Kajii, Y.: Export of atmospheric mercury from Asia, Atmos. Environ., 39, 3029-3038, 2005.

Kellerhals, M., Beauchamp, S., Balzer, W., Blanchard, P., Froude, F., Harvey, B., McDonald, K., Pilote, M., Poissant, L., Puckett, K., Schroeder, B., Steffen, A., and Tordon, R.: Temporal and spatial variability of total gaseous mercury in Canada: results from the Canadian Atmospheric Mercury Measurement Network (CAMNet), Atmos. Environ. 37, 1003-1011, 2003.

Landis, M. S., Stevens, R. K., Schaedlich, F., and Prestbo, E. M.: Development and chracterization of an annular denuder methodology for the measurement of divalent inorganic reactive gaseous mercury in ambient air, Environ. Sci. Technol., 36, 3000-3009, 2002.

Lin, C.-J., Pongprueksa, P., Lindberg, S. E., Pehkonen, S. O., Byun, D., and Jang, C.: Scientific uncertainties in atmospheric mercury models. I. Model science evaluation, Atmos. Environ, 40, 29112928, 2006.

Lindberg, S. E., Turner, R. R., Meyers, T. P., Taylor Jr., G. E., and Schroeder, W. H.: Atmospheric concentrations and deposition of $\mathrm{Hg}$ to a deciduous forest at Walker Branch watershed, Tennessee, USA, Water Air Soil Poll. 56, 577-594, 1991.

Lindberg, S., Bullock, R., Ebinghaus, R., Engstrom, D., Feng, X., Fitzgerald, W., Pirrone, N., Prestbo, E., and Seigneur, C.: A synthesis of progress and uncertainties in attributiin the sources of mercury in deposition, Ambio, 36, 19-32, 2007.

Maiss, M., Steele, L. P., Francey, R. J., Fraser, P. J., Langenfelds, R. L., Trivett, N. B. A., and Levin, I.: Sulfur hexafluoride - a powerful new atmospheric tracer, Atmos. Environ. 30, 1621-1629, 1996.

Martinsson, B. G.: An external beam PIXE/PESA setup for characterization of fine aerosols, Nucl. Instrum. Methods, B22, 356363, 1987.

Mergler, D., Anderson, H. A., Chan, L. H. M., Mahaffey, K. R., Murray, M., Sakamoto, M., and Stern, A. H.: Methyl mercury exposure and Health effects in humans: A worldwide concern, Ambio, 36, 3-11, 2007.

Munthe, J., Wängberg, I., Pirrone, N., Iverfeldt, A., Ferrara, R., Ebinghaus, R., Feng, X., Gardfeldt, K., Keeler, G., Lanzillotta, E., Lindberg, S. E., Lu, J., Mamane, Y., Prestbo, E., Schmolke, S., Schroeder, W. H., Sommar, J., Sprovieri, F., Szevens, R. K., Stratton, W., Tuncel, G., and Urba, A.: Intercomparison of methods for sampling and analysis of atmospheric mercury species, Atmos. Environ, 35, 3007-3017, 2001.

Murphy, D. M., Thomson, D. S., and Mahoney, M. J.: In situ measurements of organics, meteoritic material, mercury, and other elements in aerosols at 5 to 19 kilometers, Science, 282, 16641669, 1998.

Murphy, D. M., Hudson, P. K., Thomson, D. S., Sheridan, P. J., and Wilson, J. C.: Observations of mercury-containing aerosols, Environ. Sci. Technol., 40, 3163-3167, 2006.

Pan, L. L., Randel, W. J., Gary, B. L., Mahoney, M. J., and Hintsa, E. J.: Definitions and sharpness of the extratropical 
tropopause: A trace gas perspective, J. Geophys. Res., 109, D23103, doi:10.1029/2004JD004982, 2004.

Prestbo, E. M. and Bloom, N. S.: Mercury speciation absorption (MESA) method for combustion flue gas: methodology, artifacts, intercomparisons, and atmospheric implications, Water Air Soil Poll., 80, 145-158, 1995.

Radke, L. F., Friedli, H. R., and Heikes, B. G.: Atmospheric mercury over the NE Pacific during spring 2002: Gradients, residence time, upper troposphere lower stratosphere loss, and long-range transport, J. Geophys. Res., 112, D19305, doi:10.1029/2005JD005828, 2007.

Scheele, M., Siegmund, P., and Van Velthoven, P.: Sensitivity of trajectories to data resolution and its dependence on the starting point: In or outside a tropopause fold, Meteorol. Appl., 3, 267273, 1996.

Scheuhammer, A. M., Meyer, M. W., Sandheinrich, M. B., and Murray, M. W.: Effects of environmental methylmercury on the health of wild bird, mammals, and fish, Ambio, 36, 12-18, 2007.

Schroeder, W. H. and Munthe, J.: Atmospheric mercury - an overview, Atmos. Environ., 32, 809-822, 1998.

Selin, N. E., Jacob, D. J., Park, R. J., Yantosca, R. M., Strode, S., Jaeglé, L., and Jaffe, D.: Chemical cycling and deposition of atmospheric mercury: Global constraints from observations, J. Geophys. Res., 112, D02308, doi:10.1029/2006JD007450, 2007.

Slemr, F., Schuster, G., and Seiler, W.: Distribution, speciation, and budget of atmospheric mercury, J. Atmos. Chem., 3, 407-434, 1985.

Slemr, F. and Scheel, H. E.: Trends in atmospheric concentrations at the summit of the Wank Mountain, Southern Germany, Atmos. Environ., 32, 845-853, 1998.

Slemr, F., Ebinghaus, R., Simmonds, P. G., and Jennings, S. G.: European emissions of mercury derived from long-term observations at Mace Head, on the western Irish coast, Atmos. Environ., 40, 6966-6974, 2006.

Slemr, F., Brunke, E.-G., Labuschagne, C., and Ebinghaus, R.: Total gaseous mecrury concentrations at the Cape Point GAW station and their seasonality, Geophys. Res. Lett., 35, L11807, doi:10.1029/2008GL033741, 2008.

Stiller, G. P., von Clarmann, T., Höpfner, M., Glatthor, N., Grabowski, U., Kellmann, S., Kleinert, A., Linden, A., Milz, M., Reddmann, T., Steck, T., Fischer, H., Funke, B., LópezPuertas, M., and Engel, A.: Global distribution of mean age of stratospheric air from MIPAS SF 6 measurements, Atmos. Chem. Phys., 8, 677-695, 2008,

http://www.atmos-chem-phys.net/8/677/2008/.
Strobel, H. A.: Chemical Instrumentation, Addison-Wesley Publ Co., London, 427 pp., 1973.

Swartzendruber, P. C., Jaffe, D. A., Prestbo, E. M., Weiss-Penzias, P., Selin, N. E., Park, R., Jacob, D. J., Strode, S., and Jaeglé, L.: Observations of resctive gaseous mercury in the free troposphere at the Mount Bachelor Observatory, J. Geophys. Res., 111, D24301, doi:10.1029/2006JD007415, 2006.

Swartzendruber, P. C., Chand, D., Jaffe, D. A., Smith, J., Reidmiller, D., Gratz, L., Keeler, J., Strode, S., Jaeglé, L., and Talbot, R.: Vertical distribution of mercury, CO, ozone, and aerosol scattering coefficient in the Pacific Northwest during the spring 2006 INTEX-B campaign, J. Geophys. Res., 113, D10305, doi:10.1029/2007JD009579, 2008.

Talbot, R., Mao, H., Scheuer, E., Dibb, J., and Avery, M.: Total depletion of $\mathrm{Hg}^{\circ}$ in the upper troposphere - lower stratosphere, Geophys. Res. Lett., 34, L23804, doi:10.1029/2007GL031366, 2007.

Talbot, R., Mao, H., Scheuer, E., Dibb, J., Avery, M., Browell, E., Sachse, G., Vay, S., Blake, D., Huey, G., and Fuelberg, H.: Factors influencing the large-scale distribution of $\mathrm{Hg}^{\circ}$ in the Mexico City area and over the North Pacific, Atmos. Chem. Phys., 8, 2103-2114, 2008, http://www.atmos-chem-phys.net/8/2103/2008/.

Temme, C., Einax, J. W., Ebinghaus, R., and Schroeder, W. H.: Measurements of atmospheric mercury species at a coastal site in the Antarctic and over the South Atlantic Ocean during polar summer, Environ. Sci. Technol., 37, 22-31, 2003a.

Temme, C., Slemr, F., Ebinghaus, R., and Einax, J. W.: Distribution of mercury over the Atlantic Ocean in 1996 and 1999-2001, Atmos. Environ., 37, 1889-1897, 2003b.

Weiss-Penzias, P., Jaffe, D., Swartzendruber, P., Hafner, W., and Chand, D.: Quantifying Asian and biomass burning sources of mercury using the $\mathrm{Hg} / \mathrm{CO}$ ratio in pollution plumes observed at the Mount Bachelor Observatory, Atmos. Environ., 41, 43664379, 2007.

York, D.: Least-square fitting of a straight line, Can. J. Phys., 44, 1079-1086, 1966.

Zahn, A., Brenninkmeijer, C. A. M., Asman, W. A. H., Crutzen, P. J., Heinrich, G., Fischer, H., Cuijpers, J. W. M., and van Velthoven, P. F. J.: Budgets of $\mathrm{O}_{3}$ and $\mathrm{CO}$ in the upper troposphere: CARIBIC passenger aircraft results 1997-2001, J. Geophys. Res., 107(D17), 4337, doi:10.1029/2001JD001529, 2002. 